\title{
Investigations on the Triboelectrostatic Charging Behaviour and the Triboelectrostatic Sortability of Different Oxides
}

\author{
Sabrina Gehringer, Christoph Luckeneder, and Helmut Flachberger
}

Chair of Mineral Processing, Department Mineral Resources Engineering, Montanuniversitaet Leoben, Leoben, Austria

Received September 23, 2020; accepted September 25, 2020; published online October 14, 2020

\begin{abstract}
In the course of this study, several test series were carried out to investigate the triboelectrostatic charging behaviour of various oxides. At the beginning, the influence of the degree of aging and the influence of the sample storage on the charging efficiency of the oxide samples was analysed. For this purpose, two oxide samples were stored under different environmental conditions and then sorted using triboelectrostatic belt separation. Results of a previous series of tests showed that an increased feed temperature has a negative effect on the charging behaviour of calcium and magnesium oxide. Therefore, the effects of a reduced feed temperature were also examined. For these experiments, samples were stored at $8^{\circ} \mathrm{C}$ under exclusion of air. In addition, a series of tests was carried out with a gradual increase of the voltage on the triboelectrostatic belt separator in order to determine possible differences in the charging efficiency of calcium oxide and magnesium oxide and to subsequently use them for the separation.
\end{abstract}

Keywords: Electrostatic separation, Mineral processing, Caustic calcined magnesite, Magnesium oxide, Dry processing investigations, Controlled charging of mineral surfaces

Untersuchungen zum triboelektrostatischen Aufladeverhalten und zur triboelektrostatischen Sortierbarkeit verschiedener Oxide

Zusammenfassung: Im Zuge dieser Studie wurden mehrere Versuchsreihen durchgeführt, um das triboelektrostatische Aufladeverhalten verschiedener Oxide zu untersuchen. Zu Beginn wurde der Einfluss des Alterungsgrades und der Einfluss der Probenlagerung auf die Aufladung

\footnotetext{
Dipl.-Ing. S. Gehringer $(\varangle)$

Chair of Mineral Processing, Department Mineral Resources Engineering,

Montanuniversitaet Leoben,

Franz-Josef-Str. 18

8700 Leoben, Austria

sabrina.gehringer@unileoben.ac.at
}

von Oxiden analysiert. Zu diesem Zweck wurden zwei Oxid-Chargen bei unterschiedlichen Umgebungsbedingungen gelagert und anschließend mittels triboelektrostatischer Bandscheidung sortiert. Da in einer vorangehenden Versuchsreihe festgestellt wurde, dass sich eine erhöhte Aufgabetemperatur negativ auf das Aufladeverhalten von Kalzium- und Magnesium-Oxiden auswirkt, wurden ergänzend dazu die Auswirkungen einer gesenkten Aufgabetemperatur untersucht. Für diese Versuche wurden Proben bei $8^{\circ} \mathrm{C}$ unter Luftabschluss gelagert. Zusätzlich wurde noch eine Versuchsreihe mit stufenweiser Erhöhung der Spannung am triboelektrostatischen Bandscheider durchgeführt, um mögliche Unterschiede der Aufladeeffizienz von Calciumoxid und Magnesiumoxid festzustellen und diese in weiterer Folge für die Sortierung auszunutzen.

Schlüsselwörter: Elektrostatische Sortierung, Mineralaufbereitung, Kaustisch gebrannter Magnesit, Magnesiumoxid, Trockene Sortierverfahren, Gezielte Aufladung von Mineraloberflächen

\section{Introduction}

The company "Styromag Steirische Magnesitindustrie $\mathrm{GmbH}^{\prime \prime}$ provided the samples for the separation tests. The main and valuable component of these samples is magnesium oxide, accompanying components are silicon dioxide and calcium oxide. In a previous study "Processing of caustic calcined magnesite (magnesium oxide) by the use of triboelectrostatic belt separation" [1] the depletion of the silicon dioxide succeeded. A separation of calcium and magnesium oxide was not achieved in the course of these experiments.

Based on the results of this previous study the charging behaviour of the contained oxides was analysed in more detail in order to expand the acquired basic knowledge and to find a way to separate calcium and magnesium oxide.

For the production of the oxide samples, raw magnesite was burned at temperatures below $900^{\circ} \mathrm{C}$, which causes 
a (magnesium-) oxide product with a moderate to high level of reactivity [2].

Because of the reactivity, it is an imperative to search for dry processing techniques for the separation of such oxides. In case of the application of a wet processing technology, the burnt oxides transform to their hydroxides and influence the product quality and applicability in a negative way [1].

\section{Experimentation}

The experimental work for this study was carried out in an air-conditioned room of the Chair of Mineral Processing at the Montanuniversitaet Leoben with a triboelectrostatic belt separator of type "ST X2" provided by ST Equipment \& Technology LLC (STET).

\subsection{Triboelectrostatic Belt Separator}

The separation of two non-conductors in an electrostatic field by utilization of triboelectric charging is implemented by free-fall separators or belt separators. The technology of separation in the triboelectric field including the belt separators are described at length in Wills' Mineral Processing Technology [3] and Ullmann's Encyclopedia of Industrial Chemistry [4].

The separation tests presented within this paper were conducted with a triboelectric belt separator called "ST X2" manufactured by STET for laboratory purposes. The operational principle of the "ST X2" is explained in [1]. A graphic representation of the sorting process can be seen in Fig. 1.

\section{Sample Characterisation}

In the course of these experiments two oxide samples were analysed. The main and valuable component of both samples is magnesium oxide, accompanying components are silicon dioxide and calcium oxide. The samples were labelled with "batch $A$ " (produced 6 months before the ex-
TABLE 1

Chemical composition in the particle size classes of both oxide samples (batch $A$ and batch $B$ )

\begin{tabular}{|lllllll}
\hline & \multicolumn{3}{c}{ Batch $\mathrm{A}$} & \multicolumn{5}{c}{ Batch $\mathrm{B}$} \\
\hline Fraction & $\mathrm{MgO}$ & $\mathrm{CaO}$ & $\mathrm{SiO}_{2}$ & $\mathrm{MgO}$ & $\mathrm{CaO}$ & $\mathrm{SiO}_{2}$ \\
\hline$[\mu \mathrm{m}]$ & {$[\%]$} & {$[\%]$} & {$[\%]$} & {$[\%]$} & {$[\%]$} & {$[\%]$} \\
\hline$>100$ & 51.25 & 20.06 & 9.15 & 61.40 & 12.90 & 6.60 \\
\hline $100 / 80$ & 63.01 & 10.13 & 6.25 & 72.20 & 7.30 & 4.20 \\
\hline $80 / 63$ & 75.15 & 7.38 & 5.07 & 78.00 & 6.20 & 2.60 \\
\hline $63 / 40$ & 83.48 & 4.37 & 2.93 & 81.70 & 4.10 & 2.90 \\
\hline $40 / 0$ & 85.77 & 3.63 & 2.86 & 84.10 & 3.40 & 2.90 \\
\hline
\end{tabular}

periments) and "batch B" (produced in the month of the experiments).

In order to get an impression of the mineral phase distribution in the grain size classes of both oxide batches, a sieve analysis (100, 80,63 and $40 \mu \mathrm{m})$ was carried out and the chemical composition was determined in the different fractions. Fig. 2 shows the particle size distribution of the two analysed oxide batches in logarithmic grid. The more recently produced batch $B$ has a coarser particle size distribution than the older batch $A$.

Table 1 and Fig. 3 show the chemical composition in the different fractions. The $\mathrm{MgO}$ content increases with decreasing particle size, the two accompanying components $\mathrm{CaO}$ and $\mathrm{SiO}_{2}$ show an inverse trend. Both batches result in a silimar characteristic.

As part of the sample characterisation, the reactivity of both oxide batches against an aqueous citric acid solution $(0.15 \mathrm{~mol} / \mathrm{l})$ was determined in order to check if there is a relationship between sample age or reactivity and charging efficiency. The neutralisation speed is an indicator for reactivity and therefore also for the degree of aging of oxide samples [6].

The $\mathrm{pH}$ curves for the neutralisation reaction are shown in Fig. 4. The measurement was carried out twice for each sample. The $\mathrm{pH}$ value increases significantly for the newer batch $\mathrm{B}$ compared to the older batch $\mathrm{A}$.
Fig. 1: Operation principle of a triboelectrostatic belt separator [5]

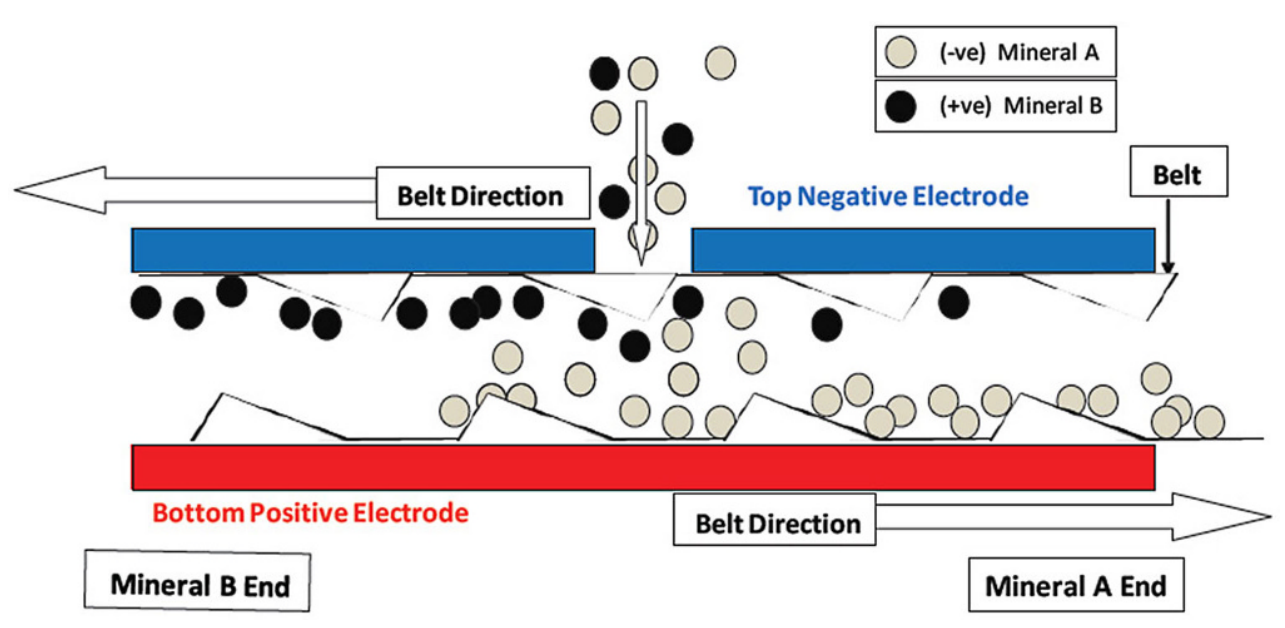




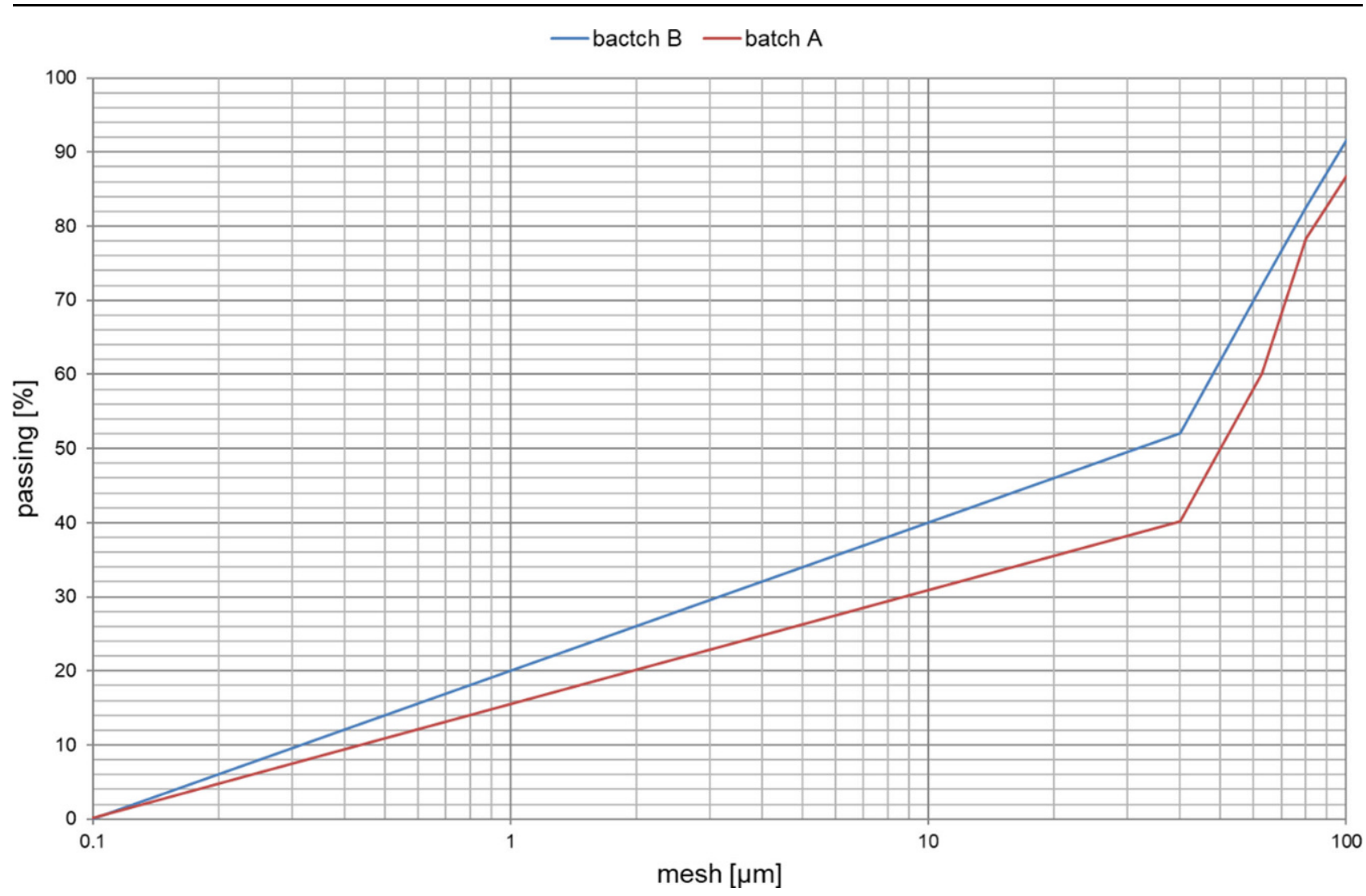

Fig. 2: Particle size distribution of both oxide samples (batch $A$ and batch $B$ ) in the logarithmic grid

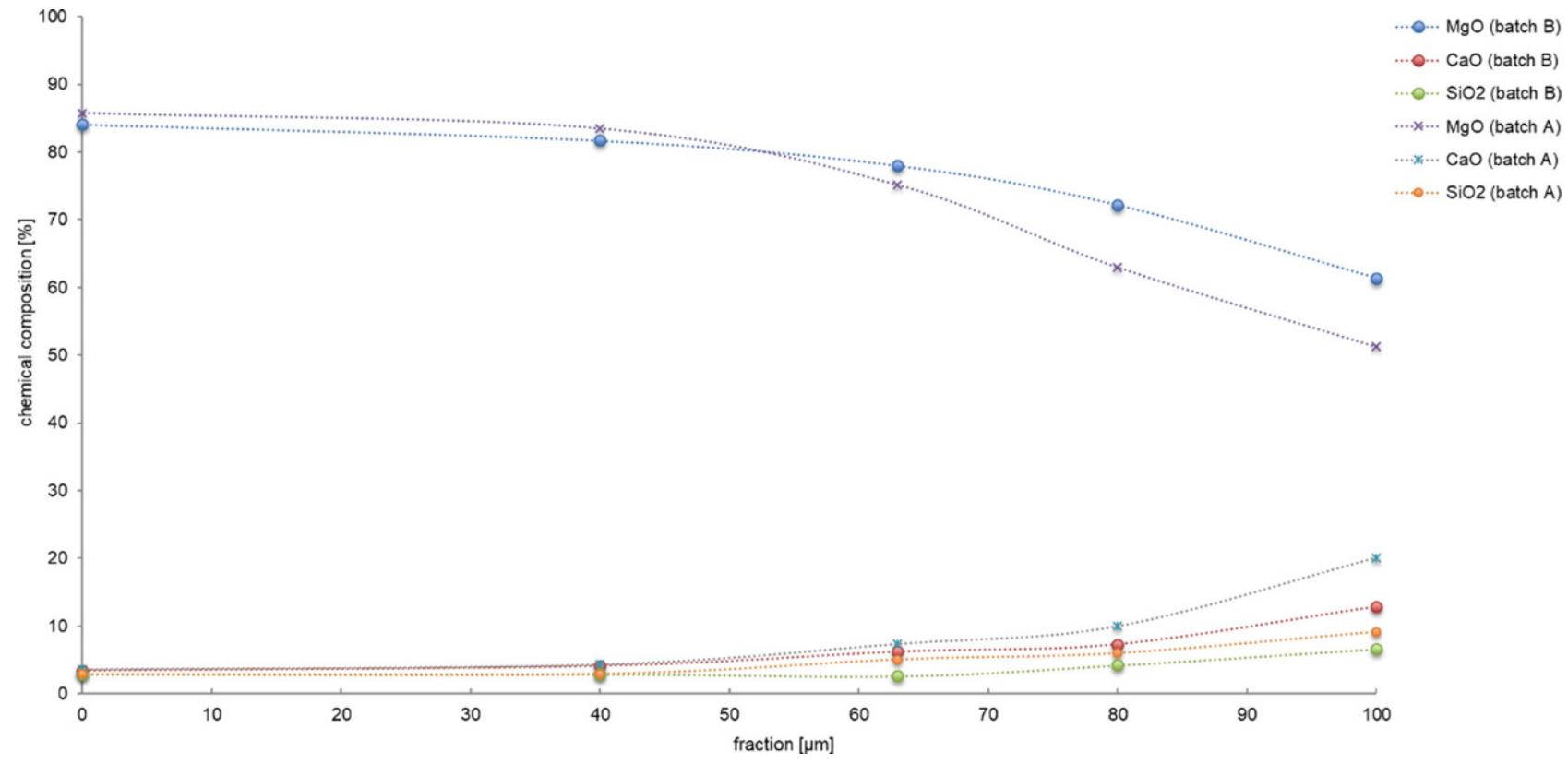

Fig. 3: Chemical composition in relation to the fractions of both oxide samples (batch A and batch B) 


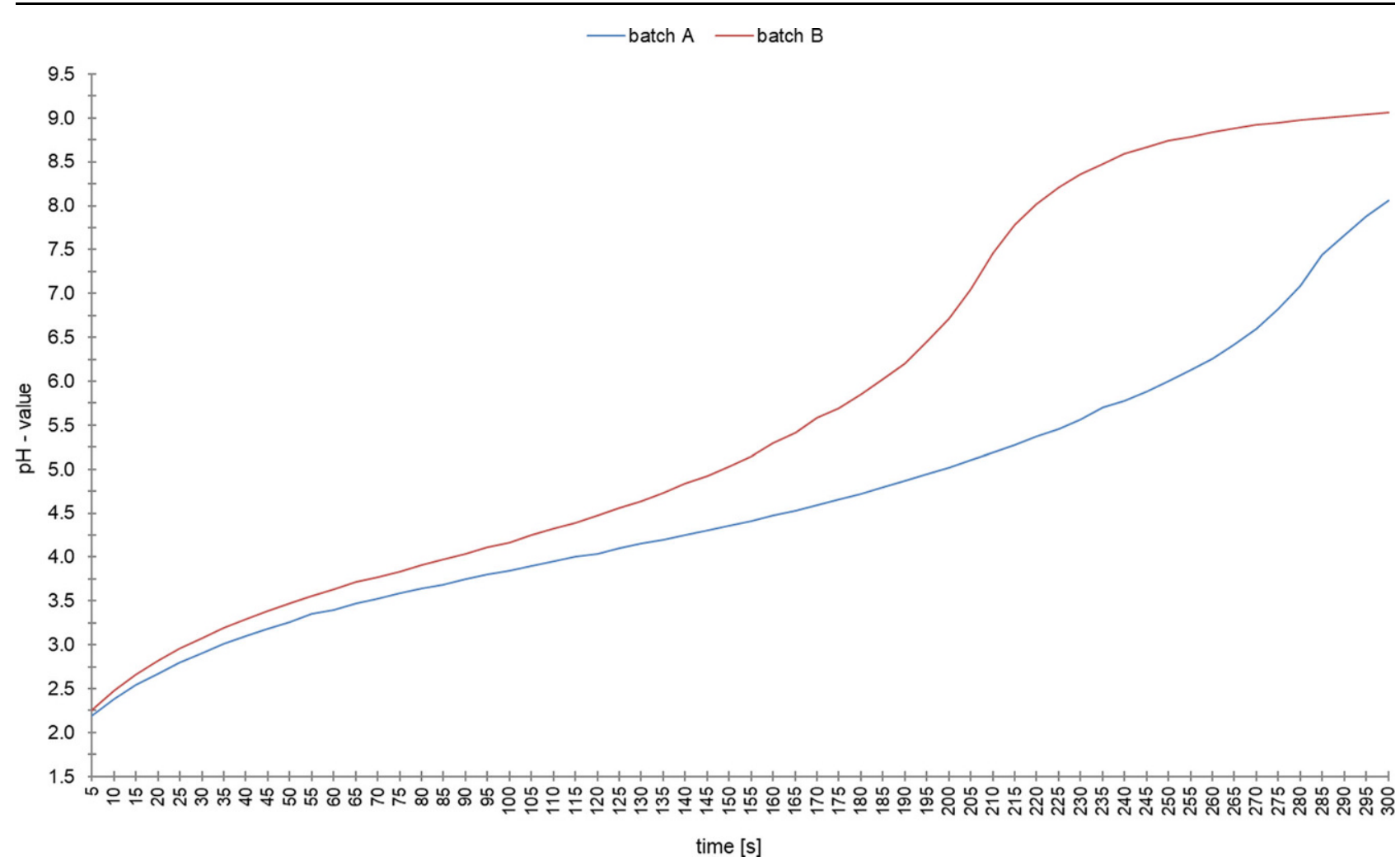

Fig. 4: Reactivity to citric acid of both oxide batches (batch A and batch B)

\begin{tabular}{|llllll|}
\hline $\begin{array}{l}\text { TABLE 2 } \\
\text { Storage conditions for the oxide samples }\end{array}$ \\
\hline $\begin{array}{l}\text { Storage } \\
\text { condition } \\
\text { number }\end{array}$ & $\begin{array}{l}\text { Time } \\
{[\mathrm{h}]}\end{array}$ & $\begin{array}{l}\text { Tempera- } \\
\text { ture } \\
{\left[{ }^{\circ} \mathrm{C}\right]}\end{array}$ & $\begin{array}{l}\text { Relative } \\
\text { humidity } \\
{[\%]}\end{array}$ & Location \\
\hline 1 & 100 & 25 & 40 & Open in the lab \\
\hline 2 & 100 & 80 & 0 & Drying oven \\
\hline 3 & 100 & 20 & 25 & Climatic chamber \\
\hline
\end{tabular}

\begin{tabular}{|lllll|}
\hline $\begin{array}{l}\text { TABLE 3 } \\
\text { Optimal machine parameters for sorting test on the } \\
\text { triboelectrostatic belt separator }[1,7]\end{array}$ & \\
\hline $\begin{array}{lllll}\text { Belt } \\
\text { speed }\end{array}$ & $\begin{array}{l}\text { Gap between } \\
\text { the electrodes }\end{array}$ & $\begin{array}{l}\text { Applied } \\
\text { voltage }\end{array}$ & $\begin{array}{l}\text { Polarity of the } \\
\text { top electrode }\end{array}$ & $\begin{array}{l}\text { Feed } \\
\text { rate }\end{array}$ \\
\hline$[\mathrm{fps}]$ & {$[\mathrm{mm}]$} & {$[\mathrm{kV}]$} & $(+/-)$ & $(1-10)$ \\
\hline 35 & 9 & 6 & $(+)$ & 5 \\
\hline
\end{tabular}

\section{Influence of the Sample History}

To check whether different storage conditions affect the triboelectrostatic charging behaviour, the two oxide batches ( $A$ and $B$ ) were stored for approximately $100 \mathrm{~h}$ under the conditions shown in Table 2.

The machine parameters for the separation of the oxide samples at the triboelectrostatic belt separator (Table 3) were determined in the previous study "Processing of caustic calcined magnesite (magnesium oxide) by the use of triboelectrostatic belt separation" [1, 7].

The results of the sorting tests with the different stored oxide samples are summarized in Table 4. Storage at high relative humidity resulted in the least $\mathrm{MgO}$ grade in the concentrate (E2) in both batches. The $\mathrm{CaO}$ grade shows the same tendency for batch $B$; for batch $A$, this hardly differs between storage under normal room conditions and in the climate chamber. The recovery of $\mathrm{SiO}_{2}$ in the concentrate is lowest for batch $B$ after sample storage under normal room conditions, but highest for batch $A$. The highest values for $\mathrm{MgO}$ and $\mathrm{CaO}$ output of both batches were achieved when the samples were stored in a drying oven, followed by cooling to room temperature with the exclusion of air. This leads to the conclusion that the influence of air humidity has a negative effect on the charging behaviour of calcium and magnesium oxide.

\section{Separation Tests with Decreasing Feed Temperature}

As determined in the course of the experiments on the influence of the feed temperature [1], increasing the feed temperature to approximately $60^{\circ} \mathrm{C}$ has a negative effect on the triboelectrostatic charging of calcium and magnesium oxide. In addition to these tests, the samples were packed airtight for $24 \mathrm{~h}$, stored in the laboratory refrigerator at $8^{\circ} \mathrm{C}$ and then sorted at the triboelectrostatic belt separator, to check how decreasing the feed temperature affects the sorting success. The machine parameters were set according to Table 2. The tests were executed with batch $B$.

The results of the sorting tests with decreased feed temperature $\left(8^{\circ} \mathrm{C}\right)$ for the two oxide batches are summarized in Table 5. The experiments with decreased feed temperature 


\begin{tabular}{|c|c|c|c|c|c|c|c|c|}
\hline $\begin{array}{l}\text { Batch/storage } \\
\text { condition }\end{array}$ & Product & $\begin{array}{l}\text { Recovery } \\
{[\%]}\end{array}$ & \multicolumn{2}{|l|}{$\mathrm{SiO}_{2}$} & \multicolumn{2}{|l|}{$\mathrm{CaO}$} & \multicolumn{2}{|l|}{$\mathrm{MgO}$} \\
\hline \multicolumn{9}{|l|}{ Batch A } \\
\hline \multirow{3}{*}{$\begin{array}{l}\text { Storage } \\
\text { condition nr. } 1\end{array}$} & E1 (tailings) & 14.3 & 8.4 & 65.9 & 4.7 & 13.6 & 76.2 & 13.3 \\
\hline & E2 (concentrate) & 85.7 & 0.7 & 34.1 & 4.9 & 86.4 & 82.9 & 86.7 \\
\hline & Feed & 100.0 & 1.8 & 100.0 & 4.9 & 100.0 & 81.9 & 100.0 \\
\hline \multirow{3}{*}{$\begin{array}{l}\text { Storage } \\
\text { condition nr. } 2\end{array}$} & E1 (tailings) & 14.4 & 16.9 & 78.0 & 3.5 & 10.8 & 70.5 & 12.4 \\
\hline & E2 (concentrate) & 85.6 & 0.8 & 22.0 & 4.9 & 89.2 & 84.0 & 87.6 \\
\hline & Feed & 100.0 & 3.1 & 100.0 & 4.7 & 100.0 & 82.0 & 100.0 \\
\hline \multirow{3}{*}{$\begin{array}{l}\text { Storage } \\
\text { condition nr. } 3\end{array}$} & E1 (tailings) & 15.1 & 15.4 & 79.4 & 4.6 & 14.5 & 69.8 & 12.9 \\
\hline & E2 (concentrate) & 84.9 & 0.7 & 20.6 & 4.8 & 85.5 & 83.5 & 87.1 \\
\hline & Feed & 100.0 & 2.9 & 100.0 & 4.8 & 100.0 & 81.4 & 100.0 \\
\hline \multicolumn{9}{|l|}{ Batch B } \\
\hline \multirow{3}{*}{$\begin{array}{l}\text { Storage } \\
\text { condition nr. } 1\end{array}$} & E1 (tailings) & 29.3 & 8.7 & 83.5 & 5.7 & 32.4 & 74.4 & 27.0 \\
\hline & E2 (concentrate) & 70.7 & 0.7 & 16.5 & 5.0 & 67.6 & 83.7 & 73.0 \\
\hline & Feed & 100.0 & 3.0 & 100.0 & 5.2 & 100.0 & 81.0 & 100.0 \\
\hline \multirow{3}{*}{$\begin{array}{l}\text { Storage } \\
\text { condition nr. } 2\end{array}$} & E1 (tailings) & 13.4 & 18.2 & 81.7 & 4.0 & 10.3 & 68.8 & 11.3 \\
\hline & E2 (concentrate) & 86.6 & 0.6 & 18.3 & 5.4 & 89.7 & 84.0 & 88.7 \\
\hline & Feed & 100.0 & 3.0 & 100.0 & 5.2 & 100.0 & 82.0 & 100.0 \\
\hline \multirow{3}{*}{$\begin{array}{l}\text { Storage } \\
\text { condition nr. } 3\end{array}$} & E1 (tailings) & 17.4 & 14.3 & 81.4 & 5.7 & 18.6 & 67.4 & 14.5 \\
\hline & E2 (concentrate) & 82.6 & 0.7 & 18.6 & 5.3 & 81.4 & 83.7 & 85.5 \\
\hline & Feed & 100.0 & 3.1 & 100.0 & 5.3 & 100.0 & 80.9 & 100.0 \\
\hline
\end{tabular}

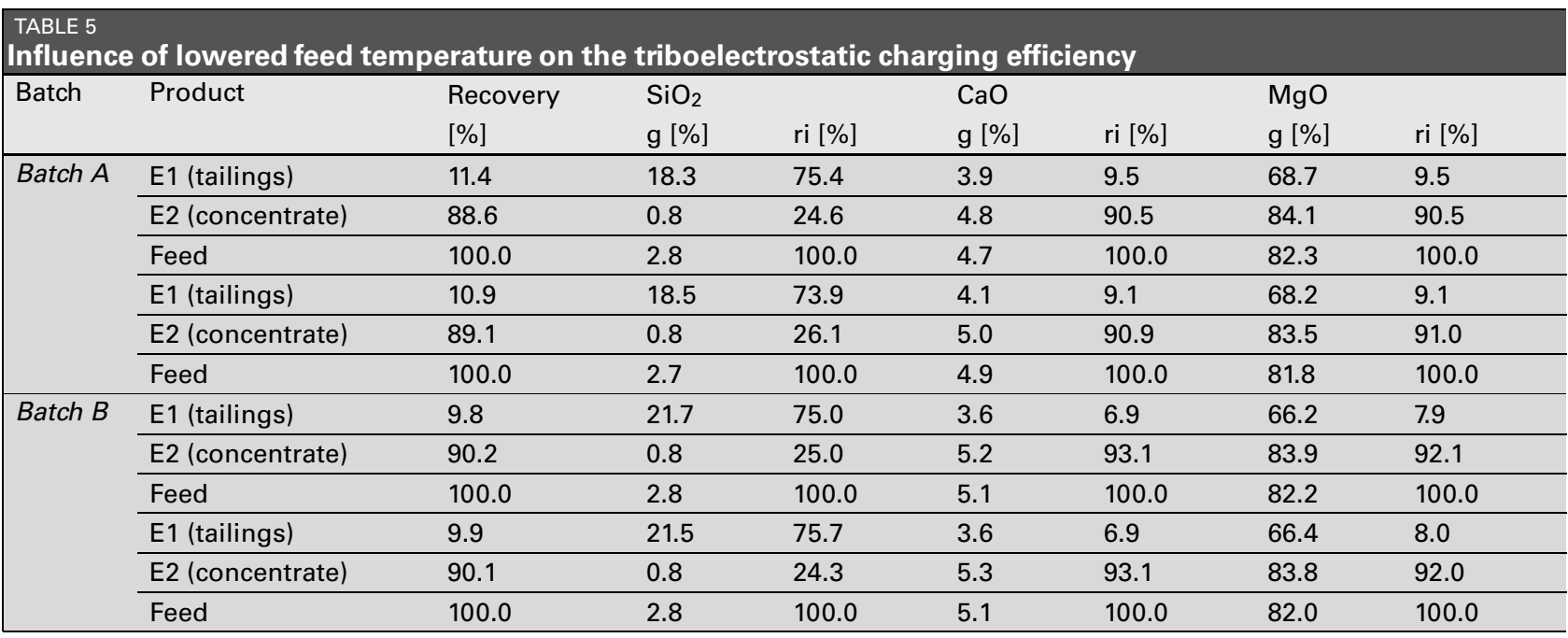

showed the highest recovery of $\mathrm{MgO}$ achieved so far for both batches. The same trend was observed for the $\mathrm{CaO}$ recovery. This leads to the assumption that lowering the feed temperature results in an improvement in the charging efficiency of calcium and magnesium oxide.

\subsection{Separation Test with Gradual Increase of Voltage}

In order to check the possibility of separating calcium and magnesium oxide, the intensity of the voltage was gradually increased. The products were analysed for each test with different voltage settings. The tests were executed with batch $B$. The four other parameters on the belt separator listed in Table 2 were kept constant. Table 6 summarises the balance sheets for the tests with gradual increase of the voltage. The recovery of $\mathrm{CaO}$ and $\mathrm{MgO}$ shows the same trend for the different voltage settings. For this reason, these two oxides cannot be separated from one another simply by changing the voltage intensity. 


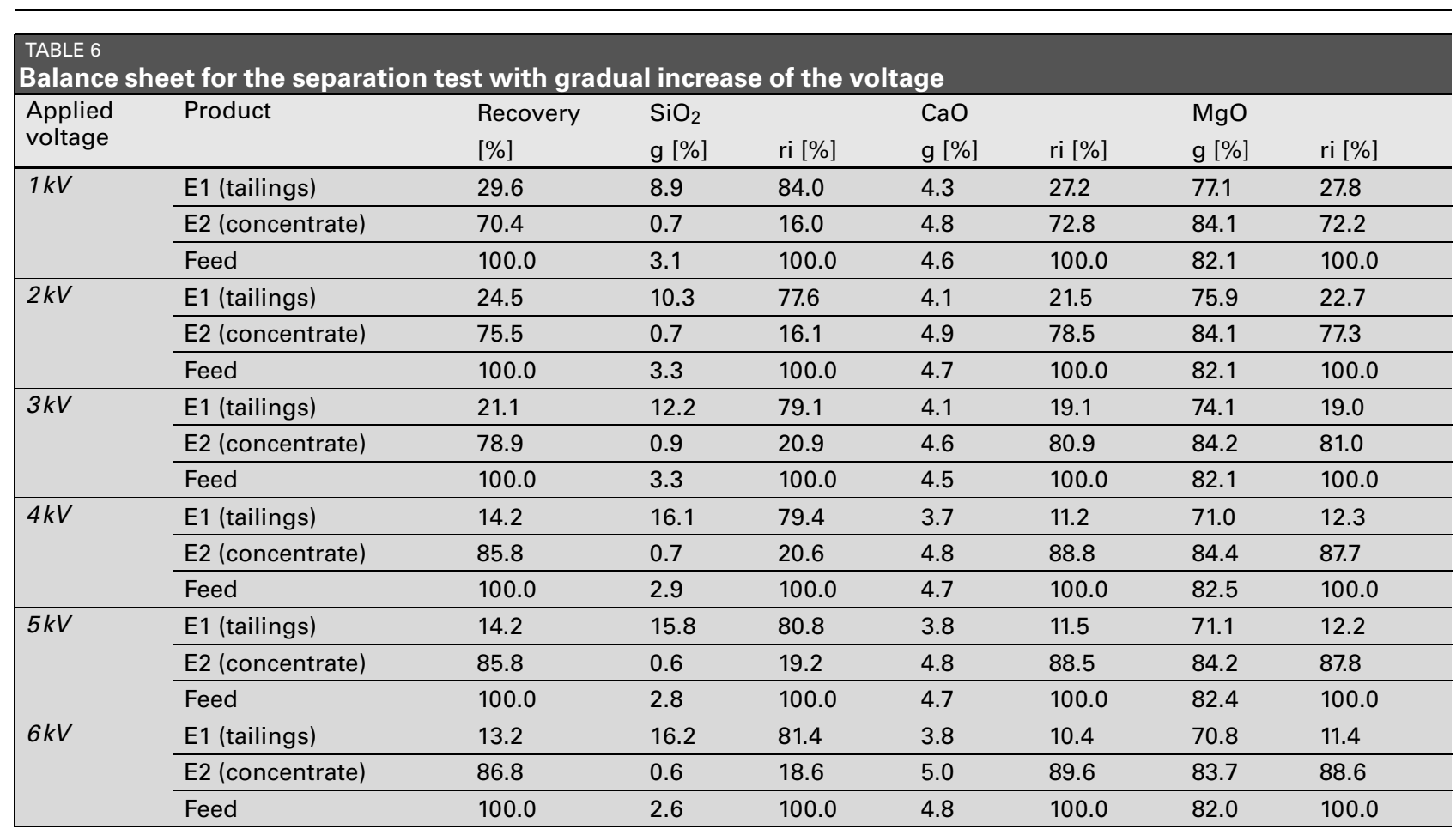

\section{Summary}

Storage in a drying oven $\left(100^{\circ} \mathrm{C}\right)$ with subsequent cooling to room temperature with exclusion of air had a positive effect on the sorting success of calcium and magnesium oxides against silicon dioxide. This effect was more pronounced in batch $\mathrm{B}$. The recovery of $\mathrm{MgO}$ in the concentrate was increased from 73.0 to $88.7 \%$ compared to open storage in the laboratory. The achieved $\mathrm{MgO}$ grade for this test was $84.0 \%$.

The trials with a reduced feed temperature (storage in a laboratory refrigerator at $8^{\circ} \mathrm{C}$ ) led to the highest $\mathrm{MgO}$ recovery (for batch $\mathrm{B}$ ) in the concentrate, so about $92.1 \%$ with a $\mathrm{MgO}$ grade of $83.9 \%$ were achieved. The same trend was observed for the $\mathrm{CaO}$ grade in the concentrate.

The experiments with a gradual increase in voltage confirmed that calcium and magnesium oxide show the same triboelectrostatic charging trend and therefore there is no possibility of separating $\mathrm{MgO}$ and $\mathrm{CaO}$ without additional feed pre-treatment.

\section{Conclusions}

As has also been found in previous studies, calcium and magnesium oxide and silicon dioxide charge in opposite directions. This trend also persists for different degrees of aging and storage conditions.

The separation of calcium and magnesium oxide is a much more complex issue. With an increasing age of the sample, which means that part of these oxides converts to hydroxide, leads to a more inefficient electrostatic charge. This manifests itself in less calcium and magnesium ox- ide grades in the concentrate when sorting by means of a triboelectrostatic belt separation.

The aging process is accelerated by contact with air of normal and high relative humidity, which is also reflected in the sorting results of the differently stored samples.

As determined by the experiments with a gradual increase in voltage, calcium and magnesium oxide have an almost identical charging behaviour. In order to enable separation of these two oxides, a special raw material pre-treatment must be taken into account [8].

Chemical conditioning could be considered for this procedure in order to either increase or suppress the charging of the surfaces of one of the two oxides, based on knowledge from other surface-active sorting processes, such as flotation.

Funding. Open access funding provided by Montanuniversität Leoben.

Open Access This article is licensed under a Creative Commons Attribution 4.0 International License, which permits use, sharing, adaptation, distribution and reproduction in any medium or format, as long as you give appropriate credit to the original author(s) and the source, provide a link to the Creative Commons licence, and indicate if changes were made. The images or other third party material in this article are included in the article's Creative Commons licence, unless indicated otherwise in a credit line to the material. If material is not included in the article's Creative Commons licence and your intended use is not permitted by statutory regulation or exceeds the permitted use, you will need to obtain permission directly from the copyright holder. To view a copy of this licence, visit http://creativecommons.org/licenses/by/4.0/.

\section{References}

1. Gehringer, S.; Flachberger, $\mathrm{H}_{\text {; }}$ Luckeneder, C.; Hrach, F: Processing of caustic calcined magnesite (magnesium oxide) by the use of triboelectrostatic belt separation, BHM Berg- und Hüttenmännische Monatshefte 164 (2019), pp 303-309 
2. Alvaradoa, E.; Torres-Martineza, L.M.; Fuentesa, A.F.; Quintana, P. Preparation and characterization of $\mathrm{MgO}$ powders obtained from different magnesium salts and the mineral dolomite, Polyhedron, 19 (2000), iss. 22-23, November 2000, pp 2345-2351

3. Wills, B.A.; Finch, J.A. (Eds.): Wills' Mineral Processing Technology, 8. Ed., Elsevier, 2016, ISBN 978-0-08-097053-0

4. Dötterl, M. et al.: Electrostatic separation, in: Ullmann's Encyclopedia of Industrial Chemistry, Weinheim: Wiley Online Library, 2016, https://doi.org/10.1002/14356007.b02_20.pub2

5. Hrach, F; Flynn, K.; Miranda, P.J.: Beneficiation of industrial minerals using a tribo-electrostatic belt separator, XXVIII International Mineral Processing Congress (IMPC) 2016, Quebec City, Canada: Canadian Institute of Mining, Metallurgy and Petroleum (CIM), 2016
6. Marbun, B.: Kinetik der Hydratation von $\mathrm{CaO}$ und $\mathrm{MgO}$, Doctoral Thesis, Fakultät für Natur- und Materialwissenschaften der Technischen Universität Clausthal, 2006

7. Gehringer, S.; Luckeneder, C.; Flachberger, H.: Triboelectrostatic belt-separation of caustic calcined magnesite, 15th Minisymposium Verfahrenstechnik and 6th Partikelforum, Leoben, April 29th-30th, 2019, Conference Proceedings

8. Manouchehri, H.-R.: Triboelectric Charge Characteristics and Electrical Separation of Industrial Minerals, Doctoral Thesis, Department of Chemical and Metallurgical Engineering Division of Mineral Processing, Luleå University of Technology, 2000

Publisher's Note. Springer Nature remains neutral with regard to jurisdictional claims in published maps and institutional affiliations. 